\title{
Hazard Analysis and Risk Assessment for an Automated Unmanned Protective Vehicle*
}

\author{
Torben Stolte ${ }^{1}$, Gerrit Bagschik ${ }^{1}$, Andreas Reschka ${ }^{1}$, and Markus Maurer ${ }^{1}$
}

\begin{abstract}
For future application of automated vehicles in public traffic, ensuring functional safety is essential. In this context, a hazard analysis and risk assessment is an important input for designing functionally vehicle automation systems. In this contribution, we present a detailed hazard analysis and risk assessment (HARA) according to the ISO 26262 standard for a specific Level 4 application, namely an unmanned protective vehicle operated without human supervision for motorway hard shoulder roadworks.
\end{abstract}

\section{INTRODUCTION}

The automation of the driving task is probably the most challenging field of research in the automotive context. Level 4 and Level 5 systems - according to the definition of SAE [1] - combine the unlimited set of operational scenarios encountered in public traffic with the absence of human supervision. This implies highest demands regarding functional safety throughout the development of these systems. Thus, the applicability of the ISO 26262 standard [2] - the most recent standard for designing safety-relevant electronic systems in the automotive context - must be examined.

Following the ISO 26262 standard, a hazard analysis and risk assessment (HARA) is required in order to determine the criticality of the system under consideration. The results of the HARA strongly influence the efforts to be undertaken in the subsequent development steps for ensuring functional safety. Normally, the results of HARAs are not published and thus cannot be discussed in the scientific community due to reasons of non-disclosure. This also applies to the field of vehicle automation.

However, exceptionally high demands regarding system implementation and its safety result from the missing human supervision. Hence, in-depth discussions about functional safety are crucial before deploying automated vehicles in public traffic. In this contribution, we present the complete results of a HARA conducted for a specific Level 4 application. The paper structures as follows: We introduce the project aFAS and the functionality to be implemented in the project in Section III. In Section III. we define relevant terms, describe the HARA approach, and highlight important

\footnotetext{
*The project aFAS is partially funded by the German Federal Ministry of Economics and Technology (BMWi). The project consortium consists of MAN (consortium leader), ZF TRW, WABCO, Bosch Automotive Steering, Technische Universität Braunschweig, Hochschule Karlsruhe, Hessen Mobil - Road and Traffic Management, and BASt - Federal Highway Research Institute. We would like to thank our partners and colleagues for their support of our work as well as the reviewers for the high quality review.

${ }^{1}$ Torben Stolte, Gerrit Bagschik, Andreas Reschka, and Markus Maurer are with the Institute of Control Engineering at Technische Universität Braunschweig, 38106 Braunschweig, Germany. \{stolte, bagschik, reschka, maurer\}@ifr.ing.tu-bs.de
}

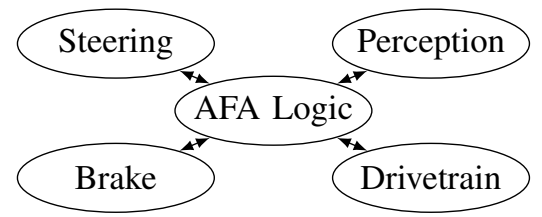

Fig. 1. Dependence of AFA Logic and connected elements results. Finally, Section IV contains the implications on designing vehicle automation systems. Complete results of the conducted HARA can be taken from the Appendix.

\section{System Description \& Project Context}

The project aFAS ${ }^{2}$ aims at developing an unmanned operation of a protective vehicle (AFA ${ }^{3}$ ) on the hard shoulder of highways in Germany, cf. [3]. The vehicle is operated without supervision on hard shoulders only and with low speed of up to $12 \mathrm{~km} / \mathrm{h}$. The automated operation consists of three operating modes complemented by the Manual Mode which comprises the normal operation of the AFA with a human driver. Safe Halt serves as initial operating mode as well as for switching between Follow Mode and Coupled Mode. Furthermore, Safe Halt is activated if the system leaves functional system boundaries. In Follow Mode, the AFA follows the leading vehicle, which conducts the actual work such as cleaning the hard shoulder, in a defined distance of about $90 \mathrm{~m}$. To follow the leading vehicle and to stay on the hard shoulder, the AFA perceives the leading vehicle as well as lane markings of the hard shoulder by environment sensors. In Coupled Mode, the AFA follows the leading vehicle in close distance of about $10 \mathrm{~m}$ in order to pass acceleration and deceleration lanes. This is primarily realized through motion data of the leading vehicle. For transmitting system states and commands (e.g. changes of operating modes), the vehicles communicate via radio.

For the HARA presented in the following (cf. Section III), we concentrated on the parts that are specific for the automated operation in order to reduce the complexity that arises when considering the entire vehicle. The considered functionality is summarized in terms of the item ${ }^{4}$ called AFA Logic. However, for unmanned operation additional elements are required, namely drivetrain, brakes, steering and environment perception. These elements are connected with the AFA Logic as depicted in Fig. 1. Hence, safety requirements can be inherited between connected elements.

\footnotetext{
${ }^{2}$ German abbreviation for "Automated Unmanned Protective Vehicle for Highway Hard Shoulder Road Works"

${ }^{3}$ German abbreviation for "Automated Unmanned Protective Vehicle"

${ }^{4}$ Defined as "system or array of systems to implement a function at the vehicle level, to which ISO 26262 is applied" [2, 1.69]
} 


\section{HAZARD ANALYSIS AND RISK ASSESSMENT}

\section{A. Terminology}

A major contribution of the ISO 26262 standard is the definition of more than 100 terms related to functional safety of automotive electric/electronic systems. Yet, some terms must be further clarified for automated driving. In the context of the HARA, the terms hazard, hazardous event, operational situation, and malfunctioning behavior are the most common terms encountered. The term hazard [2, 1.57] is defined as "potential source of harm", which is consistent to other definitions in safety engineering, e.g. [4], [5]. The definition used in the ISO 26262 standard specifies that a hazard is caused by malfunctioning behavior. Malfunctioning behavior itself is either caused by failures or unintended behavior of the system [2, 1.73]. Hence, the definitions of hazard and malfunctioning behavior are applicable for automated driving.

Furthermore, combining operational situation and hazard yields a hazardous event [2, 1.59]. In contrast to hazard and malfunctioning behavior, the ISO 26262 standard's definitions of the terms operational situation and hazardous event are vague with respect to automated driving. A similar vagueness can be found in [4] and [5]. An operational situation is defined as "scenario that can occur during a vehicle's life" [2, 1.83], equaling the terms situation and scenario. However, both terms - together with the term scene - are widely used in the context of automated driving and must be distinguished from each other according to Ulbrich et al. [6], who present a comprehensive literature review regarding these terms. Ulbrich et al. define and substantiate a scene as an all-encompassing snapshot of an environment together with the self-representation of all actors and observers contained (objective scene). In the real world, a scene is always subjective for each observer. A situation is derived from the subjective scene perceived by a traffic participant. It contains all necessary premises to derive suitable driving decisions. A scenario is the temporal concatenation of related scenes. Hence, we utilize the term operational scenario in preference to operational situation in the following since an objective exterior view is what is required for conducting a HARA.

The vagueness of the term hazardous event results from the linguistic ambiguity of the term event. This ambiguity is not resolved in the ISO 26262 standard. Event either addresses a period of time or - in a physical/technical sense - a point of time [7]. In engineering, one would consider the latter as intended meaning, yet the temporal interpretation is meant by the ISO 26262 standard in our understanding. What is actually required for obtaining a classification of safety criticality, is an operational scenario combined with a hazard. Thus, we utilize the term hazardous scenario in preference to hazardous event in the following.

\section{B. Approach}

For conducting a HARA, a linear reference process is illustrated in the ISO 26262 standard [2, Part 3], which rather addresses the interdependencies of single steps than necessary iterations to reach completeness. Warg et al. [8] describe an iterative process for developing HARAs in the context of automated driving. The process we applied in regard to the AFA Logic is similar to the approach proposed by Warg et al. and is depicted in Fig. 2 Yet, our approach differs from the approach of Warg et al. in certain aspects and extends it as well: While Warg et al. take a preliminary feature description as initial input resulting in an item definition during the process, our process input is a well advanced item definition.

Furthermore, we introduce two loops instead of one for refining the work products. Effects of both loops on the AFA Logic are described in the following subsection. The item refinement - comparable to the function refinement of Warg et al. [8] - describes extending or (in most cases) narrowing the functional range of the item under consideration. By this means, the merely functional consideration of the item according to the ISO 26262 standard is supplemented by considering technical feasibility, e.g. due to limited project resources or not yet available technology. In contrast, the safety refinement does not affect the functional range. Rather, it aims at refining the determined hazardous scenarios in order to enable technically realizable safety concepts through reaching more precise and definite safety goals. The safety refinement is comparable to the procedure to reach completeness of HARAs of Johansson [9].

Apart from refinement, each iteration loop consists of six steps. In the first step, functionalities are extracted from the item definition. Subsequently, potential malfunctioning behavior and related hazards are derived in the second and third step, respectively. The combination of hazards and operational scenarios derived from the item definition then yields the hazardous scenarios in the fourth step. Determining Automotive Safety Integrity Levels (ASILs) and safety goals are the fifth and the sixth step in Fig. 2, which are strongly linked.

\section{Results}

We developed the HARA together with experts from the industrial members of the aFAS consortium ${ }^{1}$, in iterative group meetings. As mentioned, the complete results can be found in the Appendix. In the following, we highlight selected results that affect functional range, environment perception, human machine interface (HMI), and user interaction, as well as central control logic. Table I presents the identified safety goals. Its order - as the HARA's numbering

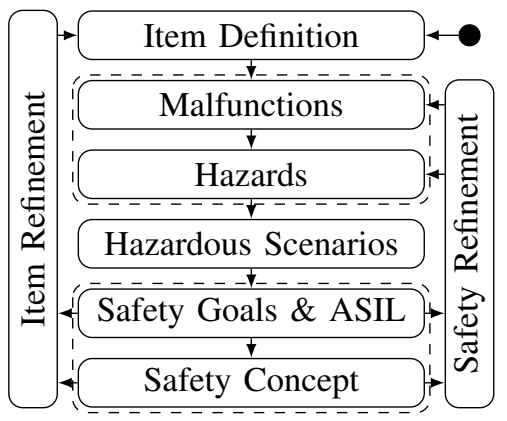

Fig. 2. Process of HARA generation and refinement 
TABLE I

Protective Vehicle's SAFEty GoAls For UnMANNEd OPERATION

\begin{tabular}{cc}
\hline ID & All operating modes \\
\hline SG01 & $\begin{array}{c}\text { Unintended and not permitted operating mode change must } \\
\text { be prevented. }\end{array}$ \\
SG02 & Intended and permitted operating mode change must be \\
ensured.
\end{tabular}

in the Appendix - illustrates the several iterations necessary to obtain a result commonly accepted among the contributors. For instance, safety goal SG16 was added in a later iteration, although strongly connected to safety goal SG04.

Initially, the functional range was supposed to include automated unmanned operation on the motorway's right lane as well, in order to be capable of driving around obstacles on the hard shoulder. During item refinement, however, the functional range was reduced, as this feature was technically too challenging due to limited project resources. Accordingly, the unmanned operation was restricted to hard shoulders as well as acceleration and deceleration lanes, both with a limited velocity of $10 \mathrm{~km} / \mathrm{h}$ (plus $2 \mathrm{~km} / \mathrm{h}$ tolerance).

An example for the above mentioned safety refinement loop are safety goals SG03 and SG12. Safety goal SG12 was established in one of the first iterations effecting high ASIL ratings on all involved components, namely environment perception, AFA Logic, and actuators. In subsequent iterations, we differentiated between unintended steering actuation beyond the specification of the item definition (up to full steering actuation) and unintended steering actuation within the specification. This results in different hazardous scenarios which were rated separately. Consequently, safety goal SG03 was introduced, which targets at limiting the maximum steering angle and thereby reduces the effects of malfunctioning behavior of other system elements. Due to the limited steering angle, the AFA will intrude the right lane of the motorway with less lateral velocity. Thus, the controllability rating can be reduced as other traffic participants can react more appropriately. By this means, the limitation of the steering angle in automated operation gains the former high ASIL rating (ASIL D) of safety goal SG12 while the rating of safety goal SG12 is reduced (ASIL B).

The previous reduction of the ASIL rating of safety goal SG12 also affects the functional block of the AFA Logic, which must be implemented with ASIL B as well. In discussions prior to the project start, a group of experts from the consortium underestimated the efforts to be undertaken for implementing the AFA Logic as well as of the human machine interaction. If the operating mode is wrongly displayed, the AFA could intrude the right lane of the motorway and cause severe accidents, cf. HARA IDs 37 and 37a in the Appendix. Consequently, the correct display of the actual operating mode must be ensured (safety goal SG07, ASIL A). Both aspects illustrate the high demands on all system parts which originate from the missing human supervision.

The HARA's results concerning the environment perception are of particular interest, since automated vehicles are operated in an open environment where they encounter an infinite set of operational scenarios. For the AFA, safety goals SG12 and SG13 address environment perception. While safety goal SG12 obtained an ASIL B rating, the detection and reaction to obstacles on the path are rated with $\mathrm{QM}$ since persons involved in the scenarios can generally control the scenarios due to the low velocity of the AFA.

As already depicted in Fig. 1, the AFA Logic is connected to further items. Although a HARA is a top-down procedure, at some points technical aspects must be considered. In the planned system implementation of the unmanned operation, the AFA Logic has access to steering and brakes. In particular, the technical implementation of the brake system creates potential for malfunctioning behavior. Therefore, the manual operation must be considered in the HARA as well. As the malfunctioning behavior can create critical outcome in several scenarios, the related safety goals obtain highest ASIL ratings. This means that elements connected to the AFA Logic inherit according safety requirements.

\section{Discussion AND RELATED WORK}

Although the functional range considered in the aFAS project is small compared to functional ranges of future automated vehicles, several implications can be derived from our experiences made. The presented HARA is primarily based on the experience and knowledge of the involved contributors from industry and academia with a range of experience from one to more than ten years. Despite the small functional range, the contributors agree on that it was challenging to take all relevant aspects into account in order to reach consistency between item definition and HARA. This reflects in the several iterations necessary to reach a common result. Using only expert knowledge might lead to missed scenarios and thus to building unsafe systems. Consequently, we expect that HARAs for systems featuring more comprehensive functional ranges must be supported by methods and tools. The approach for refining item and safety aspects described in subsection III-B appears suitable in general. However, more distinguished methods must be developed for single steps in order to gain appropriate results.

As input to the HARA process, the AFA Logic's item definition is written in natural language, supported by some tables and figures. All functionalities considered in the 
HARA were extracted manually. This was a process taking several iterations since functionalities had not been considered or had initially been defined contradictory. For items with a wider functional range, item definitions with a more extensive utilization of semi-formal or even formal notations are necessary for ensuring proper identification of all relevant functions and related malfunctioning behavior. Moreover, this eases traceability between item definition and HARA.

For targeting completeness of hazardous scenarios, different approaches for identifying hazards and operational scenarios can be found in literature. Comparable to the approach in the aFAS project, Johansson [9] suggests experts to challenge each single hazardous scenario. If they do not find additional scenarios that lead to new safety goals, the list is likely to be complete states Johansson. However, correct ASIL ratings are required besides completeness of safety goals. Thus, the aFAS consortium also considered ASIL ratings of hazardous scenarios with the same safety goals. Warg et al. [8] propose an identification of both hazards as well as operational scenarios based on tree structures. Out of the aFAS consortium, Bagschik et al. [10] propose an approach for deriving all relevant hazardous scenarios systematically by combining operating modes, functions (derived by skill graphs), malfunctions (derived by a HAZOP analysis), and scene discretization. However, suitability of these approaches still needs to be proven for systems of future automated vehicles in terms of considering all relevant scenarios. The first two approaches need to prove their suitability for automated vehicles with a wider functional range. In contrast, the approach of Bagschik et al. creates automatically an extensive list of scenarios. However, each scenario must be assessed manually regarding safety criticality.

Once hazardous scenarios are identified, the next challenge is determining the ASIL classification. As already mentioned, the classification for the unmanned operation of the AFA is based on expert knowledge. A few aspects of the exposure - such as the rate of emergency stopping vehicles - are justified by investigations of the aFAS consortium. Severity and controllability are purely based on experts' contribution. Furthermore, standards such as the SAE J2980 standard [11] are of limited contribution for the project aFAS since they do not consider operations on the hard shoulder and focus on vehicle motion control systems. In general, controllability of hazardous scenarios is very low for Level 4 or Level 5 applications with passengers. The controllability of hazardous scenarios without passengers - as in the project aFAS is determined by surrounding traffic participants. For future application of automated vehicles, methods for objectification of the parameters must be discussed. At least, evolving standards such as the SAE J2980 standard [11] towards automated driving can support a common understanding.

So far, we conclude that methods for a systematic consideration of each HARA step can be found in literature. Consequently, one can argue that a holistic systematic HARA process is beneficial, as i.a. presented by Kemmann and Trapp [12] as well as by Beckers et al. [13]. Kemmann and Trapp [12] introduce A Structured Approach for Hazard
Analysis and Risk Assessments (SAHARA), which systematically considers each HARA step. The authors consequently use model based approaches for item definition, hazard identification, as well as for classification of controllability, severity, and exposure. Beckers et al. [13] emphasize utilization of UML based notation. This ensures the traceability throughout the HARA process and enables potential for formal verification. Still, single HARA steps in the approach of Becker et al. strongly depend on expert knowledge. For both approaches, proof of applicability to automated vehicles must be furnished.

\section{CONClusion}

The example of the unmanned protective vehicle reveals challenges during a HARA for automated vehicles operated without human supervision. It was demonstrated that conventional HARA approaches are of limited suitability, especially for future applications with a wider functional range. Consequently, already existing systematic approaches must be evolved towards automated driving functionalities without human supervision. For this, an in-depth consideration of each single HARA step is required. Furthermore, for merging the two worlds of automated driving and functional safety, clarification of used terminology is crucial to reach a common understanding.

\section{REFERENCES}

[1] SAE, "Taxonomy and Definitions for Terms Related to Driving Automation Systems for On-Road Motor Vehicles," Society of Automotive Engineers, Standard J3016, 2016.

[2] ISO, "ISO 26262: Road vehicles - Functional Safety," International Organization for Standardization, Geneva, Switzerland, International Standard, 2011.

[3] T. Stolte, A. Reschka, G. Bagschik, and M. Maurer, "Towards Automated Driving: Unmanned Protective Vehicle for Highway Hard Shoulder Road Works," in 2015 IEEE 18th International Conference on Intelligent Transportation Systems (ITSC), Las Palmas, Spain, 2015.

[4] IEC, "IEC 61508: Functional safety of electrical / electronic / programmable electronic safety-related systems," International Electrotechnical Commission, International Standard, 2010.

[5] ISO, "ISO/IEC GUIDE 51: Safety Aspects - Guidelines for Their Inclusion in Standards," International Organization for Standardization, Geneva, Switzerland, International Standard, 2014.

[6] S. Ulbrich, T. Menzel, A. Reschka, F. Schuldt, and M. Maurer, "Defining and Substantiating the Terms Scene, Situation, and Scenario for Automated Driving," in 2015 IEEE 18th International Conference on Intelligent Transportation Systems (ITSC), Las Palmas, Spain, 2015.

[7] Oxford Dictionaries, "Definition of 'event' in English," https://en. oxforddictionaries.com/definition/event

[8] F. Warg, M. Gassilewski, J. Tryggvesson, V. Izosimov, A. Werneman, and R. Johansson, "Defining Autonomous Functions Using Iterative Hazard Analysis and Requirements Refinement," in Computer Safety, Reliability, and Security, A. Skavhaug, J. Guiochet, E. Schoitsch, and F. Bitsch, Eds. Cham, Germany: Springer Internat. Publishing, 2016.

[9] R. Johansson, "The Importance of Active Choices in Hazard Analysis and Risk Assessment," in CARS - Critical Automotive Applications: Robustness \& Safety, Paris, France, 2015.

[10] G. Bagschik, A. Reschka, T. Stolte, and M. Maurer, "Identification of potential hazardous events for an Unmanned Protective Vehicle," in 2016 IEEE Intelligent Vehicles Symposium (IV), 2016.

[11] SAE, "Considerations for ISO 26262 ASIL Hazard Classification," SAE International, Standard J2980, 2015.

[12] S. Kemmann and M. Trapp, "SAHARA - A Systematic Approach for Hazard Analysis and Risk Assessment," in Proceedings of the SAE World Congress 2011, Detroit, MI, USA, 2011.

[13] K. Beckers, M. Heisel, T. Frese, and D. Hatebur, "A structured and model-based hazard analysis and risk assessment method for automotive systems," in 2013 IEEE 24th International Symposium on Software Reliability Engineering (ISSRE), Pasadena, CA, USA, 2013. 


\section{APPENDIX}

Table II displays the HARA developed in the project aFAS. Omitted and alphanumeric IDs reflect the iterative process of HARA development during item and safety refinement, cf. subsection III-B. Several IDs were discarded while the ID numbering was not adjusted, in order to preserve traceability between different HARA versions.

TABLE II

Results of Hazard Analysis and Risk Assessment of the Automated Operation of the Unmanned Protective Vehicle

\begin{tabular}{|c|c|c|c|c|c|c|c|c|c|c|c|c|}
\hline ID & $\begin{array}{c}\text { Operating } \\
\text { Mode }\end{array}$ & Function & Malfunction & Hazardous Scenario and Consequence & $\mathrm{s}$ & Rationale & $\mathrm{E}$ & Rationale & $\mathrm{C}$ & Rationale & A & SG \\
\hline 1 & $\begin{array}{l}\text { Manual } \\
\text { Mode }\end{array}$ & $\begin{array}{c}\text { Operating } \\
\text { mode } \\
\text { change }\end{array}$ & $\begin{array}{l}\text { Unintended or not } \\
\text { permitted transition to } \\
\text { other operating mode }\end{array}$ & 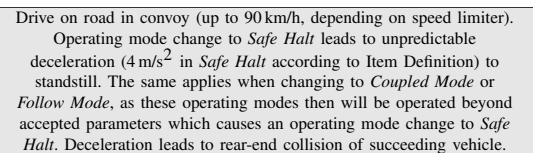 & S2 & $\begin{array}{l}\text { Assuming succeeding traffic } \\
\text { participants use seat betts and } \\
\text { brakes intuitively, the collision } \\
\text { will happen with medium velocity } \\
\text { which leads to severe injuries. }\end{array}$ & E4 & $\begin{array}{l}\text { Drive to and from location of road } \\
\text { works via roads and motorways } \\
\text { occurs for each road work. }\end{array}$ & $\mathrm{C} 2$ & $\begin{array}{l}\text { Traffic participants not complying with traffic } \\
\text { rules is commonly observable on German } \\
\text { motorways (exceeded velocities, tailgating, etc.). } \\
\text { Reaction time } 1.5 \mathrm{~s}, \text { distance } 35 \mathrm{~m} \text {, deceleration } \\
-6 \mathrm{~m} / \mathrm{s}^{2} \text {. }\end{array}$ & B & SG01 \\
\hline 2 & $\begin{array}{l}\text { Manual } \\
\text { Mode }\end{array}$ & Steer & Unintended steering & $\begin{array}{l}\text { Drive on road or motorway. Unpredictable swerving from lane leads to } \\
\text { collision with other traffic participants. }\end{array}$ & S3 & $\begin{array}{l}\text { Road: Head-on collision with } \\
\text { oncoming traffic, tree ect. } \\
\text { motorway: Collision with moving } \\
\text { traffic. Both scenario can lead to } \\
\text { severe or fatal injuries. }\end{array}$ & E4 & $\begin{array}{l}\text { Drive to and from location of road } \\
\text { works via roads and motorways } \\
\text { occurs for each road work. }\end{array}$ & $\mathrm{C} 3$ & $\begin{array}{l}\text { Experience of Bosch Automotive Steering: Full } \\
\text { steering angle due to failures is not controllable. }\end{array}$ & $\mathrm{D}$ & SG17 \\
\hline 3 & $\begin{array}{l}\text { Manual } \\
\text { Moded }\end{array}$ & Brake & $\begin{array}{l}\text { Unintended braking } \\
\text { with anti-lock } \\
\text { functionality }\end{array}$ & $\begin{array}{l}\text { Drive on road in convoy. Unpredictable maximum deceleration with } \\
\text { anti-lock functionality leads to rear-end collision of succeeding vehicle. } \\
\text { Malfunction possible due to the planned technical implementation. }\end{array}$ & S2 & $\begin{array}{l}\text { Assuming succeeding traffic } \\
\text { participants use seat belts and } \\
\text { brakes intutitively, the collision } \\
\text { will happen with medium velocity } \\
\text { which leads to severe injuries. }\end{array}$ & E4 & $\begin{array}{l}\text { Drive to and from location of road } \\
\text { works via roads and motorways } \\
\text { occurs for each road work. }\end{array}$ & $\mathrm{C} 3$ & $\begin{array}{l}\text { Traffic participants not complying with traffic } \\
\text { rules is commonly observalo on German } \\
\text { motorways (exceeded velocities, tailgating, etc.). } \\
\text { Reaction time } 1.5 \mathrm{~s} \text {, distance } 35 \mathrm{~m} \text {, deceleration }\end{array}$ & C & SG04 \\
\hline 4 & $\begin{array}{c}\text { Manual } \\
\text { Mode }\end{array}$ & Brake & $\begin{array}{l}\text { Unintended braking } \\
\text { without anti-lock } \\
\text { functionality }\end{array}$ & $\begin{array}{l}\text { Drive on road or motorway. Unpredictable maximum deceleration } \\
\text { without antitlock functionality leads to locking tires. Lateral guidance } \\
\text { is not possible, the AFA becomes uncontrollable. The AFA leaves its } \\
\text { lane and collides with stationary objects or other vehicles. Malfaunction } \\
\text { possible due to the planned technical implementation. }\end{array}$ & S3 & $\begin{array}{l}\text { Collision with uncontrollable } \\
\text { vehicle at high velocities leads to } \\
\text { severe or fatal injuries. }\end{array}$ & E4 & $\begin{array}{l}\text { Drive to and from location of road } \\
\text { works via roads and motorways } \\
\text { occurs for each road work. }\end{array}$ & $\mathrm{C} 3$ & $\begin{array}{l}\text { According to ISO26262-3, Table B4: Failure of } \\
\text { brakes } \rightarrow \text { brakes unintendedly stopping the } \\
\text { vehicle }\end{array}$ & $\mathrm{D}$ & SG16 \\
\hline 5 & $\begin{array}{l}\text { Manual } \\
\text { Mode }\end{array}$ & Drive & Unintended acceleration & $\begin{array}{l}\text { Drive on road in convoy. Unintended acceleration leads to rear-end } \\
\text { collision with preceding vehicle. }\end{array}$ & $\mathrm{s} 3$ & $\begin{array}{l}\text { Trafffic participant skids, resulting } \\
\text { crash leads to severe and } \\
\text { life-threatening injuries. }\end{array}$ & E4 & $\begin{array}{l}\text { Drive to and from location of road } \\
\text { works via roads and motorways } \\
\text { occurs for each road work. }\end{array}$ & $\mathrm{C} 0$ & $\begin{array}{l}\text { Controllable in general. Due to inertia enough } \\
\text { time for driver of AFA to react, driver brakes } \\
\text { intuitively. }\end{array}$ & QM & SG05 \\
\hline 7 & $\begin{array}{l}\text { Manual } \\
\text { Mode }\end{array}$ & HMI & $\begin{array}{l}\text { HMI displays wrong } \\
\text { operating mode }\end{array}$ & $\begin{array}{l}\text { No Hazard: Only road workers with special training are deployed on } \\
\text { AFA. In Manual Mode, the AFA is driven as usual. A wrong display of } \\
\text { operating modes leads to no more than short confusion. }\end{array}$ & so & - & E0 & - & $\mathrm{C} 0$ & - & QM & - \\
\hline 8 & Safe Halt & $\begin{array}{l}\text { Detection of } \\
\text { driver } \\
\text { intervention }\end{array}$ & $\begin{array}{l}\text { Driver intervention is } \\
\text { not detected }\end{array}$ & Test operation on hard shoulder, driver intervention is not detected. & so & $\begin{array}{l}\text { Driver intervention not detected in } \\
\text { Safe Halt does not lead to a } \\
\text { hazardous event. }\end{array}$ & E0 & $\begin{array}{l}\text { Driver intervention not detected in } \\
\text { Safe Halt does not lead to a } \\
\text { hazardous event. }\end{array}$ & $\mathrm{C} 0$ & $\begin{array}{l}\text { Driver intervention not detected in Safe Halt } \\
\text { does not lead to a hazardous event. }\end{array}$ & QM & SG06 \\
\hline 9 & Safe Halt & HмI & $\begin{array}{c}\text { HMI displays wrong } \\
\text { operating mode }\end{array}$ & $\begin{array}{l}\text { No Hazard: AFA and leading vehicle in standstill. Operating mode } \\
\text { change can only be triggered by operator in leading vehicle. }\end{array}$ & so & - & E0 & - & $\mathrm{C} 0$ & - & QM & - \\
\hline 10 & Safe Halt & $\begin{array}{l}\text { Operating } \\
\text { mode } \\
\text { change }\end{array}$ & $\begin{array}{l}\text { Unintended or not } \\
\text { permitted transition to } \\
\text { Manual Mode }\end{array}$ & $\begin{array}{l}\text { Truck convoy on right lane. AFA on hard shoulder starts to roll (slope, } \\
\text { automatic gearbox). This leads to unpredictable behavior including } \\
\text { intrusion into right lane. Truck avoids AFA, following truck touches } \\
\text { AFA as the AFA is masked by first truck. }\end{array}$ & S2 & $\begin{array}{l}\text { Collision with high differential } \\
\text { velocity, vehicles slightly touch. }\end{array}$ & E4 & $\begin{array}{l}\text { Scenario (sloped road, traffic on } \\
\text { right lane) usually met at each } \\
\text { deployment. }\end{array}$ & $\mathrm{C} 2$ & $\begin{array}{l}\text { AFA drifts slowly (e.g. } 0.4 \mathrm{~m} / \mathrm{s} \text { lateral) into } \\
\text { right triving lane. Despite of masking by truck } \\
\text { in front, following traftic is normally yable to } \\
\text { recognize this and react appropriately (braking, } \\
\text { avoiding). }\end{array}$ & в & SG01 \\
\hline 10a & Safe Halt & $\begin{array}{c}\text { Operating } \\
\text { mode } \\
\text { change }\end{array}$ & $\begin{array}{l}\text { Unintended or not } \\
\text { permitted transition to } \\
\text { Manual Mode }\end{array}$ & $\begin{array}{l}\text { Moving car traffic on right lane. AFA on hard shoulder starts to roll } \\
\text { (slope, automatic gearbox). This leads to unpredictable behavior } \\
\text { including intrusion into right lane. Car on right lane collides with } \\
\text { visible AFA. }\end{array}$ & $\mathrm{S} 3$ & $\begin{array}{l}\text { Collision with high differential } \\
\text { velocity. }\end{array}$ & E4 & $\begin{array}{l}\text { Scenario (sloped road, traffic on } \\
\text { right lane) unually met at each } \\
\text { deployment. }\end{array}$ & $\mathrm{C} 1$ & $\begin{array}{l}\text { AFA drifts slowly (e.g. } 0.4 \mathrm{~m} / \mathrm{s} \text { lateral) into } \\
\text { right driving lane. Following traffic is easily } \\
\text { able to recognize this and react appropriately } \\
\text { (braking, avoiding). }\end{array}$ & B & SG01 \\
\hline 11 & Safe Halt & $\begin{array}{c}\text { Operating } \\
\text { mode } \\
\text { change }\end{array}$ & $\begin{array}{l}\text { Unintended or not } \\
\text { permitted transition to } \\
\text { Coupled Mode }\end{array}$ & $\begin{array}{l}\text { No Hazard: Supervision works as defined in Coupled Mode. Immediate } \\
\text { operating mode change to Safe Halt sinne conditions for Coupled } \\
\text { Mode are not met (distance to leading vehicle, transmission of } \\
\text { odometry data of leading vehicle etc.) }\end{array}$ & so & - & E0 & - & $\mathrm{C} 0$ & 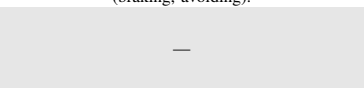 & QM & - \\
\hline 12 & Safe Halt & $\begin{array}{l}\text { Operating } \\
\text { mode } \\
\text { change }\end{array}$ & $\begin{array}{l}\text { Unintended or not } \\
\text { permitted transition to } \\
\text { Follow Mode }\end{array}$ & $\begin{array}{l}\text { No Hazard: Due to necessary boundary conditions, Follow Mode } \\
\text { cannot be retained. Operating mode changes back to Safe Halt. }\end{array}$ & so & - & E0 & - & $\mathrm{C} 0$ & - & QM & - \\
\hline 13 & Safe Halt & $\begin{array}{l}\text { Operating } \\
\text { mode } \\
\text { change }\end{array}$ & $\begin{array}{l}\text { Intended and permitted } \\
\text { transition to Manual } \\
\text { Mode is not executed }\end{array}$ & No Hazard: AFA still in standstill. & so & - & E0 & - & $\mathrm{C} 0$ & - & QM & - \\
\hline 14 & Safe Halt & $\begin{array}{l}\text { Operating } \\
\text { mode } \\
\text { change }\end{array}$ & $\begin{array}{l}\text { Intended and permitted } \\
\text { transition to Coupled } \\
\text { Mode is not executed }\end{array}$ & No Hazard: AFA still in standstill. & so & - & E0 & - & $\mathrm{C} 0$ & - & QM & - \\
\hline 15 & Safe Halt & $\begin{array}{l}\text { Operating } \\
\text { mode } \\
\text { change }\end{array}$ & $\begin{array}{l}\text { Intended and permitted } \\
\text { transition to Follow } \\
\text { Mode is not executed }\end{array}$ & No Hazard: AFA still in standstill. & so & - & E0 & - & $\mathrm{C} 0$ & - & QM & - \\
\hline 16 & Safe Halt & $\begin{array}{c}\text { Longitudinal } \\
\text { guidance }\end{array}$ & $\begin{array}{l}\text { Unintended (slow) } \\
\text { acceleration }\end{array}$ & $\begin{array}{l}\text { Truck convoy on right lane. AFA on hard shoulder starts to roll (slope, } \\
\text { automatic gearbox). This leads to unpredictable behavior including } \\
\text { intrusion into right lane. Truck avoids AFA, following truck touches } \\
\text { AFA as the AFA is masked by first truck. }\end{array}$ & $\mathrm{s} 2$ & $\begin{array}{l}\text { Collision with high differential } \\
\text { velocity, vehicles slightly touch. }\end{array}$ & E4 & $\begin{array}{l}\text { Scenario usually met at each } \\
\text { deployment. }\end{array}$ & $\mathrm{C} 2$ & $\begin{array}{l}\text { AFA drifts slowly (e.g. } 0.4 \mathrm{~m} / \mathrm{s} \text { lateral) into } \\
\text { right driving lane. Despite of maksing by truck } \\
\text { in front, following traffic is normally able to } \\
\text { recognize this and react appropriately (braking, } \\
\text { avoiding). }\end{array}$ & в & $\mathrm{SG} 08$ \\
\hline $16 \mathrm{a}$ & Safe Halt & $\begin{array}{c}\text { Longitudinal } \\
\text { guidance }\end{array}$ & $\begin{array}{l}\text { Unintended (slow) } \\
\text { acceleration }\end{array}$ & $\begin{array}{l}\text { Moving car traffic on right lane. AFA on hard shoulder starts to roll } \\
\text { (slope, automatic gearbox. This leads to unpredictable behavior } \\
\text { including intrusion into right lane. Car on right lane collides with } \\
\text { visible AFA. }\end{array}$ & s3 & $\begin{array}{l}\text { Collision with high differential } \\
\text { velocity. }\end{array}$ & E4 & $\begin{array}{l}\text { Scenario usually met at each } \\
\text { deployment. }\end{array}$ & $\mathrm{C} 1$ & $\begin{array}{l}\text { AFA drifts slowly (e.g. } 0.4 \mathrm{~m} / \mathrm{s} \text { lateral) into } \\
\text { right driving lane. Following traftic is easily } \\
\text { able to recognize this and react appropriately } \\
\text { (braking, avoiding). }\end{array}$ & в & SG08 \\
\hline
\end{tabular}


TABLE II: Continued from previous page

\begin{tabular}{|c|c|c|c|c|c|c|c|c|c|c|c|c|}
\hline ID & $\begin{array}{l}\text { Operating } \\
\text { Mode }\end{array}$ & Function & Malfunction & Hazardous Scenario and Consequence & $\mathrm{s}$ & Rationale & $\mathrm{E}$ & Rationale & C & Rationale & $\mathrm{A}$ & SG \\
\hline 17 & Safe Halt & $\begin{array}{c}\text { Longitudinal } \\
\text { guidance }\end{array}$ & $\begin{array}{l}\text { Unintended maximum } \\
\text { deceleration }\end{array}$ & $\begin{array}{l}\text { No Hazard: Maximum deceleration unproblematic, as AFA decelerates } \\
\text { from very low velocity. Morever, transition from Manual Mode to } \\
\text { Safe Halt only possible in standstill. }\end{array}$ & so & - & E0 & - & $\mathrm{C} 0$ & - & QM & - \\
\hline 18 & Safe Halt & $\begin{array}{l}\text { Longitudinal } \\
\text { guidance }\end{array}$ & No stop & $\begin{array}{l}\text { Truck convoy on right lane. As there is no environment perception } \\
\text { active in Safe enalt, intrusion into right lane is possible. Truck avoids } \\
\text { AFA, following truck touches AFA as the AFA is masked by first } \\
\text { truck. }\end{array}$ & $\mathrm{S} 2$ & $\begin{array}{l}\text { Collision with high differential } \\
\text { velocity, vehicles slightly touch. }\end{array}$ & E4 & $\begin{array}{l}\text { Safe Halt active at each } \\
\text { deployment. }\end{array}$ & C2 & $\begin{array}{l}\text { AFA drifts slowly (e.g. } 0.4 \mathrm{~m} / \mathrm{s} \text { lateral) into } \\
\text { right driving lane. Despite of masking by truck } \\
\text { in front, following traftcic is normally able to } \\
\text { recognize this and react appropriately (braking, } \\
\text { avoiding). }\end{array}$ & в & $\mathrm{SG} 09$ \\
\hline $18 \mathrm{a}$ & Safe Halt & $\begin{array}{l}\text { Longitudinal } \\
\text { guidance }\end{array}$ & No stop & $\begin{array}{l}\text { Moving car traffic on right lane. As there is no environment perception } \\
\text { active in Safe Hall, intrusion into right lane is possible. Car on right } \\
\text { lane collides with visible AFA. }\end{array}$ & $\mathrm{S} 3$ & $\begin{array}{l}\text { Collision with high differential } \\
\text { velocity. }\end{array}$ & E4 & $\begin{array}{l}\text { Safe Halt active at each } \\
\text { deployment. }\end{array}$ & $\mathrm{C} 1$ & $\begin{array}{l}\text { AFA drifts slowly (e.g. } 0.4 \mathrm{~m} / \mathrm{s} \text { laterall into } \\
\text { right driving lane. Following traffic is easily } \\
\text { able to recognize this and react appropriately } \\
\text { (braking, avoiding). }\end{array}$ & в & SG09 \\
\hline 19 & Safe Halt & $\begin{array}{l}\text { Longitudinal } \\
\text { guidance }\end{array}$ & No stop & $\begin{array}{l}\text { Obstacle, e. } g \text {. an emergency stopping vehicle, on hard shoulder. A } \\
\text { person stands between vehicle and AFA. AFA collides with vehicle. }\end{array}$ & $\mathrm{s} 2$ & $\begin{array}{l}\text { Very low velocity of AFA. Person } \\
\text { between AFA and vehicle. This is } \\
\text { expected to lead to severe yet not } \\
\text { fatal injuries }\end{array}$ & E2 & $\begin{array}{l}\text { Obstacles on hard shoulder occur } \\
\text { approximately once per week. A } \\
\text { venicle stopping between AFA } \\
\text { and leading vehile is even more } \\
\text { unlikely. }\end{array}$ & $\mathrm{C} 1$ & $\begin{array}{l}\text { People between AFA and obstacle can easily } \\
\text { react to a non-stopping AFA by stepping aside } \\
\text { due to its low velocity. }\end{array}$ & QM & SG09 \\
\hline 19a & Safe Halt & $\begin{array}{l}\text { Longitudinal } \\
\text { guidance }\end{array}$ & No stop & $\begin{array}{l}\text { Obstacle, e. g. an emergency stopping vehicle, on hard shoulder, } \\
\text { passengers in vehicle. AFA collides with vehicle. }\end{array}$ & so & $\begin{array}{l}\text { Very low velocity of AFA. No } \\
\text { injuries expected as people in } \\
\text { vehicle are protected by passenger } \\
\text { cabin. }\end{array}$ & E2 & $\begin{array}{l}\text { Obstacles on hard shoulder occur } \\
\text { approximately once per week. A } \\
\text { vehicle stopping between AFA } \\
\text { and leading venhile is even more } \\
\text { unlikely. }\end{array}$ & $\mathrm{C} 3$ & $\begin{array}{l}\text { People in a stopping vehicle only have a very } \\
\text { small chance to react to the AFA colliding } \\
\text { unexpectedly. Driver might press the brake } \\
\text { pedal intuitivively. }\end{array}$ & QM & SG09 \\
\hline 24 & $\begin{array}{l}\text { Coupled } \\
\text { Mode }\end{array}$ & $\begin{array}{c}\text { Operating } \\
\text { mode } \\
\text { change }\end{array}$ & $\begin{array}{l}\text { Unintended or not } \\
\text { permitted transition to } \\
\text { Manual Mode }\end{array}$ & 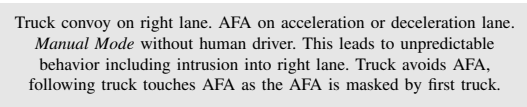 & $\mathrm{S} 2$ & $\begin{array}{l}\text { Collision with high differential } \\
\text { velocity, vehicles slightly touch. }\end{array}$ & E4 & $\begin{array}{l}\text { Passing acceleration and } \\
\text { deceleration lanes occurs on each } \\
\text { deployment. }\end{array}$ & $\mathrm{C} 2$ & $\begin{array}{l}\text { AFA drifts slowly (e.g. } 0.4 \mathrm{~m} / \mathrm{s} \text { lateral) into } \\
\text { right driving lane. Desppte of masking by truck } \\
\text { in front, following traffic is normally able to } \\
\text { recognize this and react appropriately (braking, } \\
\text { avoiding). }\end{array}$ & B & SG01 \\
\hline $24 \mathrm{a}$ & $\begin{array}{l}\text { Coupled } \\
\text { Mode }\end{array}$ & $\begin{array}{l}\text { Operating } \\
\text { mode } \\
\text { change }\end{array}$ & $\begin{array}{l}\text { Unintended or not } \\
\text { permitted transition to } \\
\text { Manual Mode }\end{array}$ & $\begin{array}{l}\text { Moving car traffic on right lane. AFA on acceleration or deceleration } \\
\text { lane. Manaul Mode without human driver. This leads to unpredictable } \\
\text { behavior including intrusion into right lane. } \\
\text { with visible AFA. Car right lane collides }\end{array}$ & s3 & $\begin{array}{l}\text { Collision with high differential } \\
\text { velocity. }\end{array}$ & E4 & $\begin{array}{l}\text { Passing acceleration and } \\
\text { deceleration lanes occurs on each } \\
\text { deployment. }\end{array}$ & $\mathrm{C} 1$ & $\begin{array}{l}\text { AFA drifts slowly (e.g. } 0.4 \mathrm{~m} / \mathrm{s} \text { lateral) into } \\
\text { right driving lane. Following traffic is easily } \\
\text { able to recognize this and react appropriately } \\
\text { (braking, avoiding). }\end{array}$ & в & SG01 \\
\hline 25 & $\begin{array}{l}\text { Coupled } \\
\text { Mode }\end{array}$ & $\begin{array}{l}\text { Operating } \\
\text { mode } \\
\text { change }\end{array}$ & $\begin{array}{l}\text { Unintended or not } \\
\text { permitted transition to } \\
\text { Safe Halt }\end{array}$ & $\begin{array}{l}\text { Moving traffic on right lane. AFA stops on acceleration or deceleration } \\
\text { lane. Vehicles entering or leaving the motorway collide with AFA. }\end{array}$ & $\mathrm{S} 2$ & $\begin{array}{l}\text { Rear-end collision with reduced } \\
\text { velocity }\end{array}$ & E4 & $\begin{array}{l}\text { Passing acceleration and } \\
\text { deceleration lanes occurs on each } \\
\text { deployment. }\end{array}$ & $\mathrm{C} 0$ & $\begin{array}{l}\text { Driver of vehicle changing to deceleration lane } \\
\text { is already braking or ready for braking. Vehicle } \\
\text { on acceleration lane in general has moderate } \\
\text { velocity. }\end{array}$ & QM & SG01 \\
\hline 26 & $\begin{array}{l}\text { Coupled } \\
\text { Mode }\end{array}$ & $\begin{array}{l}\text { Operating } \\
\text { mode } \\
\text { change }\end{array}$ & $\begin{array}{l}\text { Unintended or not } \\
\text { permitted transition to } \\
\text { Follow Mode }\end{array}$ & $\begin{array}{l}\text { Moving traffic on right lane. AFA stops on acceleration or deceleration } \\
\text { lane in order to build up required distance for Follow Mode. Vehicles } \\
\text { entering or leaving the motorway collide with AFA. }\end{array}$ & $\mathrm{S} 2$ & $\begin{array}{l}\text { Rear-end collision with reduced } \\
\text { velocity }\end{array}$ & E4 & $\begin{array}{l}\text { Passing acceleration and } \\
\text { deceleration lanes occurs on each } \\
\text { deployment. }\end{array}$ & $\mathrm{C} 0$ & $\begin{array}{l}\text { Driver of vehicle changing to deceleration lane } \\
\text { is already braking or ready for braking. Vehicle } \\
\text { on acceleration lane in general has moderate } \\
\text { velocity. }\end{array}$ & QM & $\mathrm{SG} 01$ \\
\hline 27 & $\begin{array}{l}\text { Coupled } \\
\text { Mode }\end{array}$ & $\begin{array}{l}\text { Operating } \\
\text { mode } \\
\text { change }\end{array}$ & $\begin{array}{l}\text { Intended and permitted } \\
\text { transition to Manual } \\
\text { Mode is not executed }\end{array}$ & $\begin{array}{l}\text { No Hazard: Only for tessing purposes. Driver can stop AFA } \\
\text { pneumatically by foot brake. }\end{array}$ & so & - & E0 & - & $\mathrm{C} 0$ & 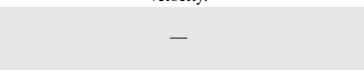 & QM & - \\
\hline 28 & $\begin{array}{l}\text { Coupled } \\
\text { Mode }\end{array}$ & $\begin{array}{c}\text { Operating } \\
\text { mode } \\
\text { change }\end{array}$ & $\begin{array}{l}\text { Intended and permitted } \\
\text { transition to Safe Halt } \\
\text { is not executed }\end{array}$ & $\begin{array}{l}\text { Truck convoy on right lane. Operating mode change to Safe Halt when } \\
\text { exceeding functional system boundaries sis not executuded. This leads to } \\
\text { unpredictable behavior including intrusion into right lane. Truck avoids } \\
\text { AFA, following truck touches AFA as the AFA is masked by first } \\
\text { trucke. }\end{array}$ & $\mathrm{S} 2$ & $\begin{array}{l}\text { Collision with high differential } \\
\text { velocity, vehicles slightly touch. }\end{array}$ & E4 & $\begin{array}{l}\text { Passing acceleration and } \\
\text { deceleration lanes occurs on each } \\
\text { deployment. }\end{array}$ & $\mathrm{C} 2$ & $\begin{array}{l}\text { AFA driftts slowly (e.g. } 0.4 \mathrm{~m} / \mathrm{s} \text { lateral) into } \\
\text { right driving lane. Despite of masking by truck } \\
\text { in front, following traffic is normally able to } \\
\text { recognize this and react approppriately (braking, } \\
\text { avoiding). }\end{array}$ & в & $\mathrm{SG} 02$ \\
\hline $28 \mathrm{a}$ & $\begin{array}{l}\text { Coupled } \\
\text { Moded }\end{array}$ & $\begin{array}{c}\text { Operating } \\
\text { mode } \\
\text { change }\end{array}$ & $\begin{array}{l}\text { Intended and permitted } \\
\text { transition to Safe Halt } \\
\text { is not executed }\end{array}$ & $\begin{array}{l}\text { Moving car traffic on right lane. Operating mode change to Safe Halt } \\
\text { when exceeding functional system boundaries is not executed. This } \\
\text { leads to unpredictable behavior including intrusion int right lane. Car } \\
\text { on right lane collides with visible AFA. }\end{array}$ & $\mathrm{S} 3$ & $\begin{array}{l}\text { Collision with high differential } \\
\text { velocity. }\end{array}$ & E4 & $\begin{array}{l}\text { Passing acceleration and } \\
\text { deceleration nanes occurs on each } \\
\text { deployment. }\end{array}$ & $\mathrm{C} 1$ & $\begin{array}{l}\text { AFA drifts slowly (e.g. } 0.4 \mathrm{~m} / \mathrm{s} \text { lateral) into } \\
\text { right driving lane. Following traffic is easily } \\
\text { able to recognize this and react appropriately } \\
\text { (braking, avoiding). }\end{array}$ & B & $\mathrm{SG} 02$ \\
\hline 30 & $\begin{array}{l}\text { Coupled } \\
\text { Mode }\end{array}$ & $\begin{array}{l}\text { Longitudinal } \\
\text { and lateral } \\
\text { guidance }\end{array}$ & $\begin{array}{l}\text { Vehicle does not follow } \\
\text { in defined distance } \\
\text { (tolerance range lateral } \\
\text { or longitudinal) }\end{array}$ & $\begin{array}{l}\text { Truck convoy on right lane. AFA follows leading vehicle with lateral } \\
\text { and longitiddinal offsets which exced the tolerance ranges. FAA is } \\
\text { partially driving on right lane. Truck avoids AFA, following truck } \\
\text { touches AFA as the AFA is masked by first truck. }\end{array}$ & $\mathrm{S} 2$ & $\begin{array}{l}\text { Collision with high differential } \\
\text { velocity, vehicles slightly touch. }\end{array}$ & E4 & $\begin{array}{l}\text { Passing acceleration and } \\
\text { deceleration lanes occurs on each } \\
\text { deployment. }\end{array}$ & $\mathrm{C} 0$ & $\begin{array}{l}\text { Traffic participants can control the AFA } \\
\text { protruding into the right lane as the warning } \\
\text { device is active as well as lateral and } \\
\text { Longitudinal guidance function as intended } \\
\text { apart from the lateral offset. }\end{array}$ & QM & SG10 \\
\hline 30a & $\begin{array}{l}\text { Coupled } \\
\text { Mode }\end{array}$ & $\begin{array}{l}\text { Longitudinal } \\
\text { and lateral } \\
\text { guidance }\end{array}$ & $\begin{array}{l}\text { Vehicle does not follow } \\
\text { in defined distance } \\
\text { (tolerance range lateral } \\
\text { or longitudinal) }\end{array}$ & $\begin{array}{l}\text { Moving car traffic on right lane. AFA follows leading vehicle with } \\
\text { lateral and longitudinal offsets which exced the tolerance ranges. AFA } \\
\text { is partially driving on right lane. Car on right lane collides with visible } \\
\text { AFA. }\end{array}$ & $\mathrm{S} 3$ & $\begin{array}{l}\text { Collision with high differential } \\
\text { velocity. }\end{array}$ & E4 & $\begin{array}{l}\text { Passing acceleration and } \\
\text { deceleration lanes occurs on each } \\
\text { deployment. }\end{array}$ & $\mathrm{C} 0$ & $\begin{array}{l}\text { Traffic participants can control the AFA } \\
\text { protruding into the right lane as the warning } \\
\text { device is active as well as lateral and } \\
\text { Longitudinal guidance function as intended } \\
\text { apart from the lateral offset. }\end{array}$ & QM & SG10 \\
\hline 31 & $\begin{array}{l}\text { Coupled } \\
\text { Mode }\end{array}$ & $\begin{array}{l}\text { Longitudinal } \\
\text { guidance }\end{array}$ & $\begin{array}{l}\text { Vehicle exceeds } \\
\text { maximum speed of } \\
12 \mathrm{~km} / \mathrm{h}\end{array}$ & 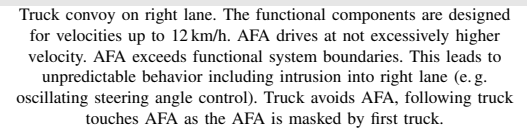 & $\mathrm{S} 2$ & $\begin{array}{l}\text { Collision with high differential } \\
\text { velocity, vehicles slightly touch. }\end{array}$ & E4 & $\begin{array}{l}\text { Passing acceleration and } \\
\text { deceleration lanes occurs on each } \\
\text { deployment. }\end{array}$ & $\mathrm{C} 2$ & $\begin{array}{l}\text { AFA drifts slowly (e. g. } 0.4 \mathrm{~m} / \mathrm{s} \text { lateral) into } \\
\text { right driving lane. Despitio of maksing by truck } \\
\text { in front, following traffic is normally able to } \\
\text { recognize this and react appropriately (braking, } \\
\text { avoiding). }\end{array}$ & B & SG11 \\
\hline $31 \mathrm{a}$ & $\begin{array}{l}\text { Coupled } \\
\text { Mode }\end{array}$ & $\begin{array}{l}\text { Longitudinal } \\
\text { guidance }\end{array}$ & $\begin{array}{l}\text { Vehicle exceeds } \\
\text { maximum speed of } \\
12 \mathrm{~km} / \mathrm{h}\end{array}$ & 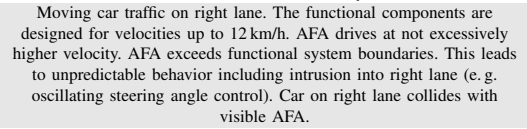 & s3 & $\begin{array}{l}\text { Collision with high differential } \\
\text { velocity. }\end{array}$ & E4 & $\begin{array}{l}\text { Passing acceleration and } \\
\text { deceleration lanes occurs on each } \\
\text { deployment. }\end{array}$ & $\mathrm{C} 1$ & $\begin{array}{l}\text { AFA drifts slowly (e. . . } 0.4 \mathrm{~m} / \mathrm{s} \text { lateral) into } \\
\text { right driving lane. Following traffic is easily } \\
\text { able to recognize this and react appropriately } \\
\text { (braking, avoiding). }\end{array}$ & B & SG11 \\
\hline 33 & $\begin{array}{l}\text { Coupled } \\
\text { Mode }\end{array}$ & $\begin{array}{l}\text { Longitudinal } \\
\text { guidance }\end{array}$ & Unintended deceleration & $\begin{array}{l}\text { Moving traffic on right lane. AFA stops on acceleration or deceleration } \\
\text { lane. Vehicles entering or leaving the motorway collide with AFA. }\end{array}$ & $\mathrm{s} 2$ & $\begin{array}{l}\text { Rear-end collision with reduced } \\
\text { velocity }\end{array}$ & E4 & $\begin{array}{l}\text { Passing acceleration and } \\
\text { deceleration lanes occurs on each } \\
\text { deployment. }\end{array}$ & $\mathrm{C} 0$ & $\begin{array}{l}\text { Driver of vehicle changing to deceleration lane } \\
\text { is already braking or ready for braking. Vehicle } \\
\text { on acceleration lane in general has moderate } \\
\text { velocity. }\end{array}$ & QM & SG04 \\
\hline
\end{tabular}


TABLE II: Continued from previous page

\begin{tabular}{|c|c|c|c|c|c|c|c|c|c|c|c|c|}
\hline ID & $\begin{array}{c}\text { Operating } \\
\text { Mode }\end{array}$ & Function & Malfunction & Hazardous Scenario and Consequence & $\mathrm{s}$ & Rationale & $\mathrm{E}$ & Rationale & c & Rationale & A & SG \\
\hline 34 & $\begin{array}{l}\text { Coupled } \\
\text { Mode }\end{array}$ & $\begin{array}{l}\text { Radio com- } \\
\text { munication }\end{array}$ & $\begin{array}{l}\text { Vehicle drives without } \\
\text { radio communication }\end{array}$ & $\begin{array}{l}\text { AFA stops due to inconsistent data of radio communication and } \\
\text { environment perception on acceleration or deceleration lane. Vehicles } \\
\text { entering or leaving the motorway collide with AFA. }\end{array}$ & S2 & $\begin{array}{l}\text { Rear-end collision with reduced } \\
\text { velocity }\end{array}$ & E4 & $\begin{array}{c}\text { Passing acceleration and } \\
\text { deceleration lanes occurs on each } \\
\text { deployment. }\end{array}$ & С0 & $\begin{array}{l}\text { Driver of vehicle changing to deceleration lane } \\
\text { is already braking or ready for braking. Vehicle } \\
\text { on acceleration lane in general has moderate } \\
\text { velocity. }\end{array}$ & QM & SG10 \\
\hline 35 & $\begin{array}{l}\text { Coupled } \\
\text { Mode }\end{array}$ & $\begin{array}{c}\text { Lateral } \\
\text { guidance }\end{array}$ & $\begin{array}{l}\text { Steering angle change } \\
\text { beyond maximum } \\
\text { specification (angle \& } \\
\text { change rate) }\end{array}$ & AFA drifts with up to maximum possible yaw rate into right lane. & S3 & $\begin{array}{l}\text { Collision with high differential } \\
\text { velocity. }\end{array}$ & E4 & $\begin{array}{l}\text { Passing acceleration and } \\
\text { deceleration lanes occurs on each } \\
\text { deployment. }\end{array}$ & $\mathrm{C} 3$ & $\begin{array}{l}\text { AFA drifts quickly (e. } . \text {. } \gg 0.4 \mathrm{~m} / \mathrm{s} \text { lateral) into } \\
\text { the right lane. It follows a circular arc to the } \\
\text { guardrail on the left of the left lane. This is } \\
\text { difficult to control by traffic participants. }\end{array}$ & $\mathrm{D}$ & $\mathrm{SG} 03$ \\
\hline 36 & $\begin{array}{l}\text { Follow } \\
\text { Mode }\end{array}$ & $\begin{array}{l}\text { Detection of } \\
\text { driver } \\
\text { intervention }\end{array}$ & $\begin{array}{l}\text { Driver intervention is } \\
\text { not detected }\end{array}$ & Test operation on hard shoulder, driver intervention is not detected. & so & $\begin{array}{l}\text { Only for testing purposes. Driver } \\
\text { can stop AFA pneumatically by } \\
\text { foot brake. }\end{array}$ & E0 & $\begin{array}{l}\text { Only for testing purposes. Driver } \\
\text { can stop AFA pneumatically by } \\
\text { foot brake. }\end{array}$ & с0 & $\begin{array}{l}\text { Only for testing purposes. Driver can stop AFA } \\
\text { pneumatically by foot brake. }\end{array}$ & QM & SG06 \\
\hline 37 & $\begin{array}{l}\text { Follow } \\
\text { Mode }\end{array}$ & HMI & $\begin{array}{l}\text { HMI displays wrong } \\
\text { operating mode }\end{array}$ & 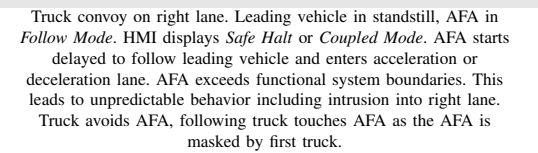 & S2 & $\begin{array}{l}\text { Collision with high differential } \\
\text { velocity, vehicles slightly touch. }\end{array}$ & E4 & $\begin{array}{l}\text { Operation on hard shoulder occurs } \\
\text { on each deployment. }\end{array}$ & $\mathrm{C} 1$ & $\begin{array}{l}\text { AFA drifts slowly (e.g. } 0.4 \mathrm{~m} / \mathrm{s} \text { lateral) into } \\
\text { right driving lane. Despite of masking by truck } \\
\text { in front, following traftic is normally able to } \\
\text { recognize this and react appropriately (braking, } \\
\text { avoiding). }\end{array}$ & A & SG07 \\
\hline 37a & $\begin{array}{l}\text { Follow } \\
\text { Mode }\end{array}$ & НMI & $\begin{array}{l}\text { HMI displays wrong } \\
\text { operating mode }\end{array}$ & $\begin{array}{l}\text { Moving car traffic on right lane. Leading vehicle in standstill, AFA in } \\
\text { Follow Mode. HMI displays Safe Halt or ocoupled Mode. AFA tharts } \\
\text { delayed to follow leading vehicle and enters acceleration or } \\
\text { deceleration lane. AFA exceeds functional system boundaries. This } \\
\text { leads to unpredictable behavior including intrusion into right lane. Car } \\
\text { on right lane collides with visible AFA. }\end{array}$ & S2 & $\begin{array}{l}\text { Collision with high differential } \\
\text { velocity. }\end{array}$ & E4 & $\begin{array}{l}\text { Operation on hard shoulder occurs } \\
\text { on each deployment. }\end{array}$ & $\mathrm{Cl}$ & $\begin{array}{l}\text { AFA drifts slowly (e.g. } 0.4 \mathrm{~m} / \mathrm{s} \text { lateral) into } \\
\text { right driving lane. Following traffic is easily } \\
\text { able to recognize this and react appropriately } \\
\text { (braking, avoiding). }\end{array}$ & A & SG07 \\
\hline 38 & $\begin{array}{l}\text { Follow } \\
\text { Mode }\end{array}$ & $\begin{array}{l}\text { Operating } \\
\text { mode } \\
\text { change }\end{array}$ & $\begin{array}{l}\text { Unintended or not } \\
\text { permitted transition to } \\
\text { Manual Mode }\end{array}$ & $\begin{array}{l}\text { Truck convoy on right lane. Manual Mode without driver. This leads to } \\
\text { unpredictable behavior including inturusion into right lane. Truck avoids } \\
\text { AFA, following truck touches AFA as the AFA is masked by first } \\
\text { truck. }\end{array}$ & S2 & $\begin{array}{l}\text { Collision with high differential } \\
\text { velocity, vehicles slightly touch. }\end{array}$ & E4 & $\begin{array}{l}\text { Operation on hard shoulder occurs } \\
\text { on each deployment. }\end{array}$ & $\mathrm{C} 2$ & $\begin{array}{l}\text { AFA drifts slowly (e.g. } 0.4 \mathrm{~m} / \mathrm{s} \text { lateral into } \\
\text { right triving lane. Despitito of masking by truck } \\
\text { in front, following traffic is normally able to } \\
\text { recognize this and react apppropriately (braking, } \\
\text { avoiding). }\end{array}$ & в & SG01 \\
\hline 38a & $\begin{array}{l}\text { Follow } \\
\text { Mode }\end{array}$ & $\begin{array}{c}\text { Operating } \\
\text { mode } \\
\text { change }\end{array}$ & $\begin{array}{l}\text { Unintended or not } \\
\text { permitted transition to } \\
\text { Manual Mode }\end{array}$ & $\begin{array}{l}\text { Moving car traffic on right lane. Manual Mode without driver. This } \\
\text { leads to unpredictable behavior including intrusion into right lane. Car } \\
\text { on right lane collides with visible AFA. }\end{array}$ & S3 & $\begin{array}{l}\text { Collision with high differential } \\
\text { velocity. }\end{array}$ & E4 & $\begin{array}{l}\text { Operation on hard shoulder occurs } \\
\text { on each deployment. }\end{array}$ & $\mathrm{Cl}$ & $\begin{array}{l}\text { AFA drifts slowly (e.g. } 0.4 \mathrm{~m} / \mathrm{s} \text { lateral) into } \\
\text { right driving lane. Following traffic is easily } \\
\text { able to recognize this and react appropriately } \\
\text { (braking, avoiding). }\end{array}$ & B & SG01 \\
\hline 41 & $\begin{array}{l}\text { Follow } \\
\text { Mode }\end{array}$ & $\begin{array}{l}\text { Follow hard } \\
\text { shoulder }\end{array}$ & $\begin{array}{l}\text { Vehicle does not follow } \\
\text { hard shoulder }\end{array}$ & $\begin{array}{l}\text { Truck convoy on right lane. AFA intrudes right lane. Truck avoids } \\
\text { AFA, following truck touches AFA as the AFA is masked by first } \\
\text { truck. }\end{array}$ & S2 & $\begin{array}{l}\text { Collision with high differential } \\
\text { velocity, vehicles slightly touch. }\end{array}$ & E4 & $\begin{array}{l}\text { Operation on hard shoulder occurs } \\
\text { on each deployment. }\end{array}$ & $\mathrm{C} 2$ & $\begin{array}{l}\text { AFA drifts slowly (e.g. } 0.4 \mathrm{~m} / \mathrm{s} \text { lateral into } \\
\text { right triving lane. Despite of masking by truck } \\
\text { in front, following traffic is normally able to } \\
\text { recognize this and react apppropriately (braking, } \\
\text { avoiding). }\end{array}$ & B & SGI2 \\
\hline 4la & $\begin{array}{l}\text { Follow } \\
\text { Mode }\end{array}$ & $\begin{array}{l}\text { Follow hard } \\
\text { shoulder }\end{array}$ & $\begin{array}{l}\text { Vehicle does not follow } \\
\text { hard shoulder }\end{array}$ & $\begin{array}{l}\text { Moving car traffic on right lane. AFA intrudes right lane. Car on right } \\
\text { lane collides with visible AFA. }\end{array}$ & S3 & $\begin{array}{l}\text { Collision with high differential } \\
\text { velocity. }\end{array}$ & E4 & $\begin{array}{l}\text { Operation on hard shoulder occurs } \\
\text { on each deployment. }\end{array}$ & $\mathrm{C} 1$ & $\begin{array}{l}\text { AFA drifts slowly (e.g. } 0.4 \mathrm{~m} / \mathrm{s} \text { lateral) into } \\
\text { right driving lane. Following traffic is easily } \\
\text { able to recognize this and react appropriately } \\
\text { (braking, avoiding). }\end{array}$ & B & SG12 \\
\hline 42 & $\begin{array}{l}\text { Follow } \\
\text { Mode }\end{array}$ & $\begin{array}{c}\text { Keep } \\
\text { defined } \\
\text { distance }\end{array}$ & $\begin{array}{l}\text { Vehicle does not follow } \\
\text { in defined tolerance } \\
\text { range }\end{array}$ & $\begin{array}{l}\text { No Hazard: AFA continues following hard shoulder based on lane } \\
\text { marking. Obstacle detection functions. AFA stops if distance to leading } \\
\text { vehicle is too large (leading vehicle out of sight, interruption of radio } \\
\text { communication). }\end{array}$ & so & - & E0 & - & $\mathrm{C} 0$ & (2) & QM & - \\
\hline 43 & $\begin{array}{l}\text { Follow } \\
\text { Mode }\end{array}$ & $\begin{array}{l}\text { Obstacle } \\
\text { detection }\end{array}$ & $\begin{array}{l}\text { Vehicle does not react } \\
\text { to obstacle }\end{array}$ & $\begin{array}{l}\text { Obstacle, e.g. an emergency stopping vehicle, on hard shoulder. A } \\
\text { person stands between vehicle and AFA. AFA collides with vehicle. }\end{array}$ & $\mathrm{S} 2$ & $\begin{array}{l}\text { Very low velocity of AFA. Person } \\
\text { between AFA and vehicle. This is } \\
\text { expected to lead to severe yet not } \\
\text { fatal injuries }\end{array}$ & E2 & $\begin{array}{l}\text { Obstacles on hard shoulder occur } \\
\text { approximately once per week. A } \\
\text { vehicle stopping between AFA } \\
\text { and leading vehicte is ven more } \\
\text { unlikely. }\end{array}$ & $\mathrm{C} 1$ & $\begin{array}{l}\text { People between AFA and obstacle can easily } \\
\text { react to a non-stopping AFA by stepping aside } \\
\text { due to its low velocity. }\end{array}$ & QM & SG13 \\
\hline $43 a$ & $\begin{array}{l}\text { Follow } \\
\text { Mode }\end{array}$ & $\begin{array}{l}\text { Obstacle } \\
\text { detection }\end{array}$ & $\begin{array}{l}\text { Vehicle does not react } \\
\text { to obstacle }\end{array}$ & $\begin{array}{l}\text { Obstacle, e. g. an emergency stopping vehicle, on hard shoulder, } \\
\text { passengers in vehicle. AFA collides with vehicle. }\end{array}$ & So & $\begin{array}{l}\text { Very low velocity of AFA. No } \\
\text { inujires expected as people in } \\
\text { vehicle are protected by passenger } \\
\text { cabin. }\end{array}$ & E2 & $\begin{array}{l}\text { Obstacles on hard shoulder occur } \\
\text { approximately once per week. A } \\
\text { vehicle stopping between AFA } \\
\text { and leading vehicle is even more } \\
\text { unlikely. }\end{array}$ & C3 & $\begin{array}{l}\text { People in a stopping vehicle only have a very } \\
\text { small chance to react to the AFA collining } \\
\text { unexpectedly. Driver might press the brake } \\
\text { pedal intuitively. }\end{array}$ & QM & SG13 \\
\hline 44 & $\begin{array}{l}\text { Follow } \\
\text { Mode }\end{array}$ & $\begin{array}{l}\text { Longitudinal } \\
\text { guidance }\end{array}$ & Unintended deceleration & $\begin{array}{l}\text { No Hazard: AFA stops on hard shoulder with active warning device } \\
\text { and transitions to Safe Halt. }\end{array}$ & so & - & E0 & - & $\mathrm{C} 0$ & - & QM & - \\
\hline 45 & $\begin{array}{l}\text { Follow } \\
\text { Mode }\end{array}$ & $\begin{array}{l}\text { Perceive } \\
\text { leading } \\
\text { vehicle }\end{array}$ & $\begin{array}{l}\text { Vehicle keeps distance } \\
\text { to wrong object }\end{array}$ & $\begin{array}{l}\text { Truck convoy on right lane. AFA follows wrong leading vehicle which } \\
\text { does not stop in front of acceleration or deceleration lanes. AFA } \\
\text { exceeds functional system boundaries. This leads to unpredictable } \\
\text { behavior including intrusion into right lane. Truck avoids AFA, } \\
\text { following truck touches AFA as the AFA is masked by first truck. }\end{array}$ & S2 & $\begin{array}{l}\text { Collision with high differential } \\
\text { velocity, vehicles slightly touch. }\end{array}$ & E1 & $\begin{array}{l}\text { Vehicle driving on hard shoulder } \\
\text { for a longer period of time and } \\
\text { with velocity } \leq 10 \mathrm{~km} / \mathrm{h} \text { occurs } \\
\qquad \text { very rarely. }\end{array}$ & C2 & $\begin{array}{l}\text { AFA drifts slowly (e.g. } 0.4 \mathrm{~m} / \mathrm{s} \text { lateral) into } \\
\text { right driving lane. Despite of masking by truck } \\
\text { in front, following traffic is normally able to } \\
\text { recogize this and react appropriately (braking, } \\
\text { avoiding). }\end{array}$ & QM & SG14 \\
\hline $45 a$ & $\begin{array}{l}\text { Follow } \\
\text { Mode }\end{array}$ & $\begin{array}{l}\text { Perceive } \\
\text { leading } \\
\text { vehicle }\end{array}$ & $\begin{array}{l}\text { Vehicle keeps distance } \\
\text { to wrong object }\end{array}$ & $\begin{array}{l}\text { Moving car traffic on right lane. AFA follows wrong leading vehicle } \\
\text { which doess not stop in front of acceleration or deceleration lanes. AFA } \\
\text { exceeds functional system boundaries. This leads to unpredictable } \\
\text { behavior including intrusion intoright lane. Car on right lane collides } \\
\text { with visible AFA. }\end{array}$ & S3 & $\begin{array}{l}\text { Collision with high differential } \\
\text { velocity. }\end{array}$ & E1 & $\begin{array}{l}\text { Vehicle driving on hard shoulder } \\
\text { for a longer period of time and } \\
\text { with velocoity } \leq 10 \mathrm{~km} / \mathrm{h} \text { occurs } \\
\text { very rarely. }\end{array}$ & $\mathrm{C} 1$ & $\begin{array}{l}\text { AFA drifts slowly (e.g. } 0.4 \mathrm{~m} / \mathrm{s} \text { lateral) into } \\
\text { right driving lane. Following traffic is easily } \\
\text { able to recognize this and react appropriately } \\
\text { (braking, avoiding). }\end{array}$ & QM & SG14 \\
\hline 46 & $\begin{array}{l}\text { Follow } \\
\text { Mode }\end{array}$ & $\begin{array}{l}\text { Perceive } \\
\text { leading } \\
\text { vehicle }\end{array}$ & $\begin{array}{l}\text { Vehicle follows hard } \\
\text { shoulder without } \\
\text { leading vehicle }\end{array}$ & $\begin{array}{l}\text { Truck convoy on right lane as well as vehicles driving on acceleration } \\
\text { and deceleration lane. AFA does not detect begin of acceleration or } \\
\text { deceleration lane. Thuss, it exceeds its functional system boundaries. } \\
\text { This leads to unpredictable behavior including intrusion into right lane. }\end{array}$ & S2 & $\begin{array}{l}\text { Collision with high differential } \\
\text { velocity, vehicles slightly touch. }\end{array}$ & E0 & $\begin{array}{l}\text { Operating instructions prohibit } \\
\text { activation of automated operation } \\
\text { without leading vehicle. }\end{array}$ & $\mathrm{C} 2$ & $\begin{array}{l}\text { AFA drifts slowly (e.g. } 0.4 \mathrm{~m} / \mathrm{s} \text { lateral) into } \\
\text { right driving lane. Despite of masking by truck } \\
\text { in front, following traffic is normally able to } \\
\text { recognize this and react appropriately (braking, } \\
\text { avoiding). }\end{array}$ & QM & SG15 \\
\hline 46a & $\begin{array}{l}\text { Follow } \\
\text { Mode }\end{array}$ & $\begin{array}{l}\text { Perceive } \\
\text { leading } \\
\text { vehicle }\end{array}$ & $\begin{array}{l}\text { Vehicle follows hard } \\
\text { shoulder without } \\
\text { leading vehicle }\end{array}$ & $\begin{array}{l}\text { Moving car traffic on right lane as well as vehicles driving on } \\
\text { acceleration and deceleration lane. AFA does not detect begin of } \\
\text { acceleration or deceleration lane. Thus, it exceeds its functional system } \\
\text { boundaries. This leads to unpredictatleb behavior including intrusion } \\
\text { into right lane. }\end{array}$ & S3 & $\begin{array}{l}\text { Collision with high differential } \\
\text { velocity. }\end{array}$ & E0 & $\begin{array}{l}\text { Operating instructions prohibit } \\
\text { activation of automated operation } \\
\text { without leading vehicle. }\end{array}$ & $\mathrm{C} 1$ & $\begin{array}{l}\text { AFA driftt slowly (e.g. } 0.4 \mathrm{~m} / \mathrm{s} \text { lateral) into } \\
\text { right driving lane. Following traftec is easily } \\
\text { able to recognize this and react appropriately } \\
\text { (braking, avoiding). }\end{array}$ & QM & SG15 \\
\hline 47 & $\begin{array}{l}\text { Follow } \\
\text { Mode }\end{array}$ & $\begin{array}{l}\text { Radio com- } \\
\text { munication }\end{array}$ & $\begin{array}{l}\text { Vehicle leaves range of } \\
\text { radio communication }\end{array}$ & $\begin{array}{l}\text { No Hazard: Interruption of of adic o ommunication causes transition to } \\
\text { Safe Halt. AFA stops on hard shoulder with active warning device. }\end{array}$ & S0 & - & E0 & - & $\mathrm{C} 0$ & - & QM & - \\
\hline
\end{tabular}


TABLE II: Continued from previous pag

\begin{tabular}{|c|c|c|c|c|c|c|c|c|c|c|c|c|}
\hline ID & $\begin{array}{c}\text { Operating } \\
\text { Mode } \\
\text { Mod }\end{array}$ & Function & Malfunction & Hazardous Scenario and Consequence & $\mathrm{s}$ & Rationale & $\mathrm{E}$ & Rationale & c & Rationale & A & SG \\
\hline 48 & $\begin{array}{l}\text { Follow } \\
\text { Mode }\end{array}$ & $\begin{array}{l}\text { Operating } \\
\text { mode } \\
\text { change }\end{array}$ & $\begin{array}{l}\text { Intended and permitted } \\
\text { transition to Safe Halt } \\
\text { is not executed }\end{array}$ & 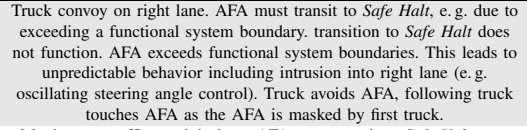 & S2 & $\begin{array}{l}\text { Collision with high differential } \\
\text { velocity, vehicles slightly touch. }\end{array}$ & E4 & $\begin{array}{l}\text { Operation on hard shoulder occurs } \\
\text { on each deployment. }\end{array}$ & $\mathrm{C} 2$ & $\begin{array}{l}\text { AFA drifts slowly (e.g. } 0.4 \mathrm{~m} / \mathrm{s} \text { lateral) into } \\
\text { right driving lane. Despite of masking by truck } \\
\text { in front, following traffic is normally able to } \\
\text { recognize this and react appropriately (braking, } \\
\text { avoiding). }\end{array}$ & B & $\mathrm{SG} 02$ \\
\hline 48a & $\begin{array}{l}\text { Follow } \\
\text { Mode }\end{array}$ & $\begin{array}{l}\text { Operating } \\
\text { mode } \\
\text { change }\end{array}$ & $\begin{array}{l}\text { Intended and permitted } \\
\text { transition to Safe Halt } \\
\text { is not executed }\end{array}$ & 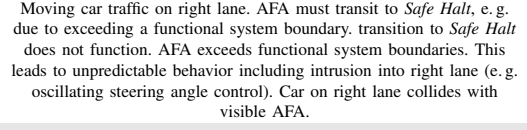 & S3 & $\begin{array}{l}\text { Collision with high differential } \\
\text { velocity. }\end{array}$ & E4 & $\begin{array}{l}\text { Operation on hard shoulder occurs } \\
\text { on each deployment. }\end{array}$ & $\mathrm{C} 1$ & $\begin{array}{l}\text { AFA drifts slowly (e. g. } 0.4 \mathrm{~m} / \mathrm{s} \text { lateral) into } \\
\text { right driving lane. Following traffic is easily } \\
\text { able to recoggize this and react appropriately } \\
\text { (braking, avoiding). }\end{array}$ & B & $\mathrm{SG} 02$ \\
\hline 49 & $\begin{array}{l}\text { Follow } \\
\text { Mode }\end{array}$ & $\begin{array}{l}\text { Operating } \\
\text { mode } \\
\text { change }\end{array}$ & $\begin{array}{l}\text { Intended and permitted } \\
\text { transition to Manual } \\
\text { Mode is not executed }\end{array}$ & $\begin{array}{l}\text { No Hazard: Only for testing purposes. Driver can stop AFA } \\
\text { pnnumatically by foot brake. }\end{array}$ & so & - & E0 & - & $\mathrm{C} 0$ & - & QM & - \\
\hline 50 & $\begin{array}{l}\text { Follow } \\
\text { Mode }\end{array}$ & $\begin{array}{l}\begin{array}{l}\text { Radio com- } \\
\text { munication }\end{array} \\
\text { mats }\end{array}$ & $\begin{array}{l}\text { Vehicle drives without } \\
\text { radio communication }\end{array}$ & $\begin{array}{l}\text { No Hazard: Detection of lane markings and obstacles as well as } H M I \\
\text { function as interded.AFA stops when leeding vericle stops according } \\
\text { work instructions before passing acceleration or deceleration lanes. } \\
\text { Then, malfunction becomes obvious by missing transition to Coupled } \\
\text { Mode. }\end{array}$ & So & - & E0 & - & $\mathrm{C} 0$ & - & QM & - \\
\hline 51 & $\begin{array}{l}\text { Follow } \\
\text { Mode }\end{array}$ & $\begin{array}{l}\text { Longitudinal } \\
\text { guidance }\end{array}$ & $\begin{array}{l}\text { Vehicle exceeds } \\
\text { maximum speed of } \\
12 \mathrm{~km} / \mathrm{h}\end{array}$ & 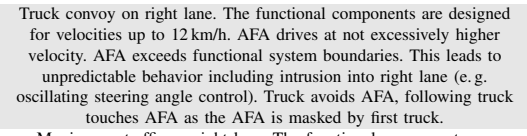 & S2 & $\begin{array}{l}\text { Collision with high differential } \\
\text { velocity, vehicles slightly touch. }\end{array}$ & E4 & $\begin{array}{l}\text { Operation on hard shoulder occurs } \\
\text { on each deployment. }\end{array}$ & C2 & $\begin{array}{l}\text { AFA drifts slowly (e. g. } 0.4 \mathrm{~m} / \mathrm{s} \text { lateral) into } \\
\text { right driving lane. Despite of masking by truck } \\
\text { in front, following traffic is normally able to } \\
\text { recognize this and react appropriately (braking, } \\
\text { avoiding). }\end{array}$ & B & SG11 \\
\hline $51 \mathrm{a}$ & $\begin{array}{l}\text { Follow } \\
\text { Mode }\end{array}$ & $\begin{array}{l}\text { Longitudinal } \\
\text { guidance }\end{array}$ & $\begin{array}{l}\text { Vehicle exceeds } \\
\text { maximum speed of } \\
12 \mathrm{~km} / \mathrm{h}\end{array}$ & 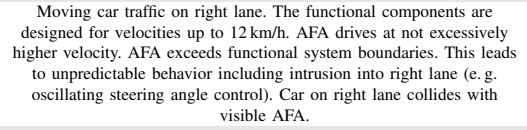 & $\mathrm{s} 3$ & $\begin{array}{l}\text { Collision with high differential } \\
\text { velocity. }\end{array}$ & E4 & $\begin{array}{l}\text { Operation on hard shoulder occurs } \\
\text { on each deployment. }\end{array}$ & $\mathrm{C} 1$ & $\begin{array}{l}\text { AFA drifts slowly (e.g. } 0.4 \mathrm{~m} / \mathrm{s} \text { lateral) into } \\
\text { right driving lane. Following traffic is easily } \\
\text { able to recognize this and react appropriately } \\
\text { (braking, avoiding). }\end{array}$ & B & SG11 \\
\hline 52 & $\begin{array}{l}\text { Follow } \\
\text { Mode }\end{array}$ & $\begin{array}{c}\text { Lateral } \\
\text { guidance }\end{array}$ & $\begin{array}{c}\begin{array}{c}\text { Steering angle change } \\
\text { beyond maximum } \\
\text { specification (angle \& } \\
\text { change rate) }\end{array} \\
\end{array}$ & AFA drifts with up to maximum possible yaw rate into right lane. & $\mathrm{s} 3$ & $\begin{array}{l}\text { Collision with high differential } \\
\text { velocity. }\end{array}$ & E4 & $\begin{array}{l}\text { Operation on hard shoulder occurs } \\
\text { on each deployment. }\end{array}$ & C3 & $\begin{array}{l}\text { AFA drifts quickly (e.g. } \gg 0.4 \mathrm{~m} / \mathrm{s} \text { lateral) into } \\
\text { the right tane. It follows a circular arc to the } \\
\text { guardrail on the left of the efett lane. This is } \\
\text { difficult to control by traffic participants. }\end{array}$ & $\mathrm{D}$ & $\mathrm{SG} 03$ \\
\hline
\end{tabular}

